\title{
A CYTOCHEMICAL STUDY OF ACID CARBOHYDRATES ON THE SURFACE OF CANDIDA LIPOLYTICA GROWN IN TWEEN 80-CONTAINING MEDIUM
}

\author{
Aline E. Nascimento ${ }^{1,2}$; Allana E. do Nascimento Shariá; Marco Antonio Barbosa de Lima²; \\ Galba Maria Campos-Takaki ${ }^{1,2^{*}}$ \\ ${ }^{1}$ Departamentos de Biologia e Química, Núcleo de Pesquisas em Ciências Ambientais, Universidade Católica de Pernambuco, \\ Recife, PE, Brasil. ${ }^{2}$ Laboratório de Imunopatologia Prof. Keizo Asami/ Microscopia Eletrônica, Universidade Federal de \\ Pernambuco, Recife, PE, Brasil
}

Submitted: June 11, 1999; Returned to authors for corrections: July 29, 1999; Approved: March 22, 2000

\begin{abstract}
Carbohydrate-containing molecules were located on the surface of Candida lipolytica by using ruthenium red in a cytochemical study. The yeast was grown in media containing Tween 80 . The surfactant, at $1.0 \%$ and $0.5 \%$, was added to the culture medium in different intervals of time, correspondent to the beginning of exponential growth phase, mid of logarithimic phase and beginning of stationary growth phase. Control cultures were grown in a medium containing glucose. The growth of the yeast in media containing glucose and Tween 80 induced changes in the pattern of distribution and location of acid polyssacharides in the cell wall of the microorganism. In adition, the pattern also changed according to Tween 80 concentration. The influence of Tween 80 on cellular carbohydrate expression is discussed.
\end{abstract}

Key words: Candida lipolytica; carbohydrate cytochemistry; fungi ultrastructure

\section{INTRODUCTION}

Candida lipolytica has been object of various biochemical and physiological studies concerning its abilities to grow and utilize hydrocarbons, methanol, acetate and fatty acids as carbon sources. It produces extracellular proteases, lipases, isocitric and citric acids. Surfactants offer a potentially valuable model system for the study of extracellular metabolites production in lower eukaryotes and potential use in industry. In addition, genetic analysis is possible due to the discovery of its sexual cycle $(12,37,38,43,44,49,60,62)$.

Non-ionic surfactants of the Tween series have been used as culture additives to improve cellular growth of bacteria and filamentous fungi and the secretion of various microbial products, particularly enzymes. The maximal stimulation is observed with Tween 80 , the only surfactant bearing an unsaturated fatty acid residue (oleate). It has been suggested that the effect of surfactants is on cell membrane permeability.
On the other hand, surfactants of Tween serie could be used to supply fatty acid to the culture. However, the mechanism through which surfactants affect enzyme production and cellular growth is not clearly understood $(3,19,39,46,52,55)$.

Many of the properties of the cell surface, which include surface antigens, hormone binding, cell recognition, adhesiveness and adsortion can be ascribed to polysaccharides or may be influenced by them $(13,27,34)$.

Acid polysaccharides contain negatively charged residues. Because of their negative charge they are highly hydrated molecules, which avidly bind cations and may form gels of varying pore size and charge density, acting in cell osmoregulation. Thus they work as sieves to regulate the traffic of ions in and out of cell and consequently in cell morphogenesis, cell differentiation and cellular growth (13).

Fungi cell wall is a prime station in the coding and decoding of regulatory signal. This cell component is involved in many cellular functions, such as morphogenetic events and cellular

\footnotetext{
* Corresponding author. Mailing address: UNICAP, Rua Nunes Machado, 42, Bloco J, Boa Vista, Recife, PE, CEP 50050-590. Fax: (+5581) 2164043
} 
interaction. It is also residence for enzymes, determines cell sensibility to drugs and the arquitecture and composition of the cell wall may vary according to environmental conditions. It is important therefore to understand the structural organization, the molecular array, the composition, and the functional properties of all components of the cell wall $(7,15,24,25,51)$.

This work was carried out to localize the acid polysaccharides in situ in Candida lipolytica cell wall and to evaluate the effects of Tween 80 on the ultrastructure by using a ultrastructural cytochemistry approach.

\section{MATERIALS AND METHODS}

\section{Microorganism and growth medium}

Candida lipolytica IA 1055 was grown in Cald Yeast Mold (CYM) medium described by Cirigliano and Carman (11) modified by Nascimento et al., (43), over $96 \mathrm{~h}$ at $27^{\circ} \mathrm{C}$ on a reciprocal shaker $(120 \mathrm{~Hz})$. Tween 80 was added to the culture medium at intervals of $0,8,16$ and $24 \mathrm{~h}$ during culture to final concentrations of $0.5 \%$ and $1.0 \%$. These intervals corresponded to the beginning of the culture, beginning of exponential growth phase, intermediary exponential growth phase, and end of exponential growth phase/beginning of stationary phase, respectively. Control cultures corresponded to those grown in same medium but added of glucose.

\section{Cytochemical analysis}

Samples of C. lipolytica cultures grown in glucose and those grown in Tween 80 were collected from the culture medium at 8 , 16 and 24 hours of growth, washed twice in phosphate buffer saline (PBS), $\mathrm{pH} 7.0$ and fixed for $1 \mathrm{~h}$ at room temperature in $2.5 \%$ glutaraldehyde in cacodylate buffer $0.1 \mathrm{M}, \mathrm{pH} 7.2$, containing $0.5 \mathrm{mg} / \mathrm{ml}$ of ruthenium red. Samples were washed twice in cacodylate buffer containing ruthenium red in concentrations cited before. The post-fixation was performed in $1.0 \%$ osmium tetroxide in cacodylate buffer $0.1 \mathrm{M}, \mathrm{pH} 7.2$ containing $0.5 \mathrm{mg} / \mathrm{ml}$ of ruthenium red during $1 \mathrm{~h}$ at room temperature. After a new washing as before, dehydration was performed at acetone $50 \%, 70 \%, 90 \%$ and $100 \%$ and embedded in Epon resin. Samples for cytochemistry control were obtained by removing the ruthenium red of all preparatory steps. Ultrathin sections were obtained in a Reichert ultracut, collected on copper grids, and examined in JEOL CX-100 transmission electron microscope $(32,33)$.

\section{RESULTS}

Thin sections of $C$. lipolytica showed a typical construction of eukaryotic cells with mitochondria, electrondense cytoplasm bodies rich in granules, and the plasma membrane exhibiting many invaginations. The thickness of the cell wall increased with cellular age (Fig. 1).

Ultrastructural cytochemistry using ruthenium red as marker of control samples (grown in presence of glucose) revealed that surface of cell wall of $C$. lipolytica presented a dense reaction product coat of fibrillar material covering the whole cell surface. The intensity of the reaction decreased with age of culture (Figs. $2 \mathrm{~A}, 2 \mathrm{~B}$ and $2 \mathrm{C}$ ).

On the other hand, cells grown in presence of Tween 80 presented different cytochemical staining pattern according to the surfactant concentration. Cells treated with $0.5 \%$ exhibited a reduced cytochemical staining compared to control samples and a decreasing of cytochemical staining according to growth phase of cultive similar to control cells (Figs. 3A, 3B and 3C).

Cells of cultures treated with Tween $1.0 \%$ exhibited the lowest cytochemical labeling in the cell wall in spite of surfactant addition time in culture medium (Figs. 4A, 4B and 4C).

The presence of reaction product observed as a coat of fibrilar material was not observed in the cell wall of control samples, which were not submitted to both cytochemical staining and contrastation (Figs. 5, 6 and 7). In these samples the cell wall was an eletronlucent space without visualization of layers.

\section{DISCUSSION}

The ultrastructure of yeast cells was first studied in 1957 and the techniques used have advanced greatly in the 40 years since then. Information about yeast cell wall composition, synthesis, genetics and structure has come from studies involving saprophytic and medically important species such as Candida albicans and Saccharomyces cerevisiae. Genetic, biochemical and ultrastructural combined approaches are essential for furthering the knowledgement of various aspects of yeast cell wall. There is little understanding of the processes that result in joint of components into a wall. A start on the problem might be based on the type of polysaccharide present in a given cell wall $(7,29,31,48)$.

Ultrastructural characteristics of the fungal cell wall, septal pore, mitochondria, nucleus, organelles and plasma membrane of many taxonomic groups, including medically important species, have been extensively studied, and already reviewed $(28,40,47,53,54,57)$. However, there is no detailed analysis of the $C$. lipolytica ultrastructure is available.

The results of this work reveal that in C. lipolytica control culture, the plasmatic membrane presents invaginations, which become longer and deeper according to the growth phase. Indeed, the cell wall became thicker during cell growth, in which distinct layers were observed. Mitochondria, eletrondense bodies, vesicles and vacuoles and an eletrondense cytoplasm were observed in the micrographs.

In yeasts, the cell wall makes 15 up to $30 \%$ of the dry weight of the cell. The walls are composed mostly of mannoproteins and fibrous and branched glycans that link other components of the wall such as chitin, as demonstrated by biochemical and degradative techniques. Carbohydrate-containing molecules 


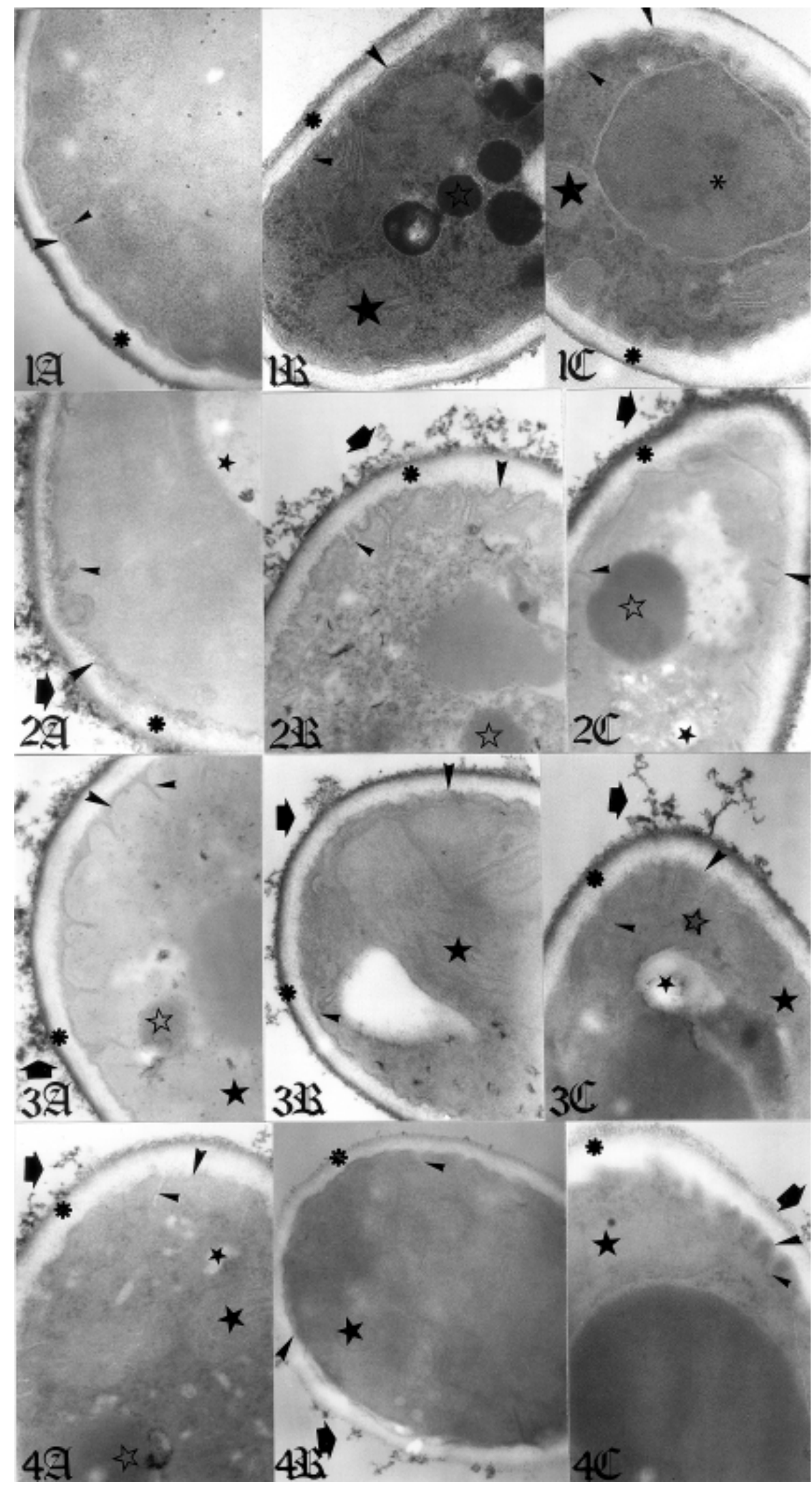

Figure 1. Candida lipolytica control culture. Cell wall (**), Cell membrane ( $>$ ), Cell membrane invaginations $(\searrow)$, Mitochondria $(\star)$, Nucleus (*), Electron dense bodies ( $(\hat{)})$. A, B and C correspond to cells with 8,16 and 24 hours of cultive. $20.000 \mathrm{X}$

Figure 2. Candida lipolytica control culture submitted to ruthenium red cytochemistry. Cell wall (苂), Cell membrane ( $)$ ), Cell membrane imaginations $(\boldsymbol{-})$, Vacuoles $(\star)$, Electron dense bodies ( $\downarrow)$. Reaction products on cell wall outer surface ( $)$. A, B and C correspond to cells with 8 , 16 and 24 hours of cultive. $20.000 \mathrm{X}$.

Figure 3. Candida lipolytica grown in presence of tween $800,5 \%$ and submitted to ruthenium red cytochemistry. Cell wall (*), Cell membrane $(\boldsymbol{)})$, Cell membrane invaginations $(>)$, Vacuoles $(\star)$, Electron dense bodies ( $خ)$, Mitochondria ( $\star$. Reaction products on cell wall outer surface ( ). A, B and C correspond to cells with 8,16 and 24 hours of cultive. 20.000X.

Figure 4. Candida lipolytica grown in presence of tween $801,0 \%$ and submitted to ruthenium red cytochemistry. Cell wall (**), Cell membrane $(\boldsymbol{)})$, Cell membrane invaginations $(\boldsymbol{})$, Vacuoles $(\star)$, Electron dense bodies $(\hbar)$, Mitochondria ( $\star$ ). Reaction products on cell wall outer surface ( ). A, B and C correspond to cells with 8,16 and 24 hours of cultive. 20.000X. 


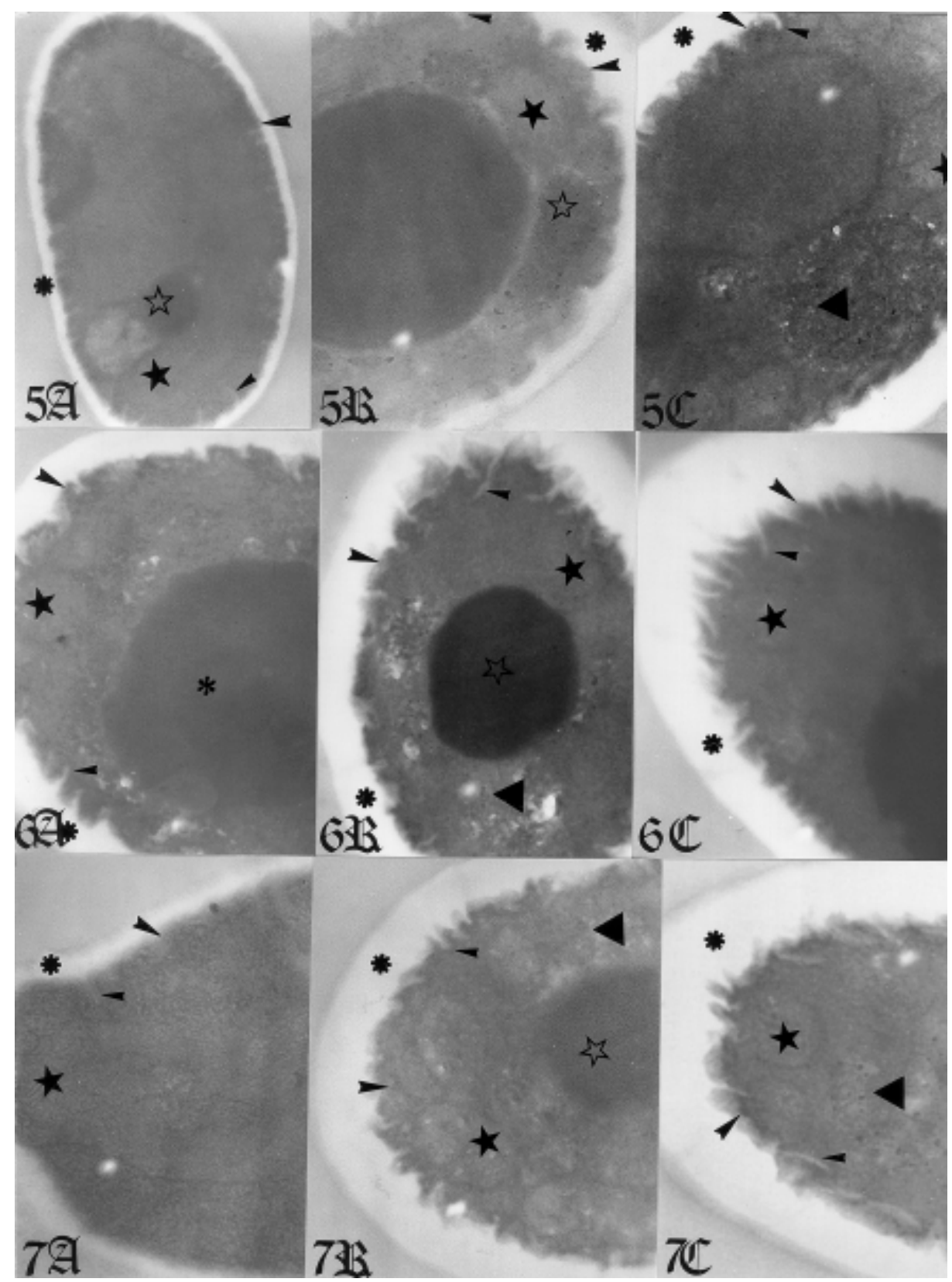

Figure 5. Candida lipolytica control culture of cytochemical labelling without constrastation. Cell wall (*), Cell membrane ( $>$ ), Cell membrane invaginations ( $>$ ), Mitochondria ( $\star$ ), Electron dense bodies ( $(2)$ ), Multivesicular bodie $(\boldsymbol{\Delta})$. A, B and C correspond to cells with 8,16 and 24 hours of cultive. 20.000X.

Figure 6. Candida lipolytica grown in presence of tween $800,5 \%$ cytochemical control. Cell wall (*), Cell membrane ( $>$ ), Cell membrane invaginations ( $\boldsymbol{\sim}$ ), Multivesicular bodie $(\boldsymbol{\Lambda})$, Electron dense bodies ( $\downarrow$ ), Mitochondria ( $\downarrow$ ), Nucleus (*). A, B and C correspond to cells with 8,16 and 24 hours of cultive. 20.000X.

Figure 7. Candida lipolytica grown in presence of tween $801,0 \%$ cytochemical control. Cell wall (**), Cell membrane ( $)$, Cell membrane invaginations $(\boldsymbol{\nabla})$, Multivesicular bodie $(\mathbf{A})$, Electron dense bodies ( $\downarrow$ ) $\mathrm{A}, \mathrm{B}$ and $\mathrm{C}$ correspond to cells with 8,16 and 24 hours of cultive. $20.000 \mathrm{X}$. have been located on the yeast cell wall by ultrastructural cytochemistry $(2,5,6,8,16,20,28,30,31,48,56)$.

Cytochemical observations of $C$. lipolytica collected from control cultures by using ruthenium red revealed an eletrondense coat of fibrillar and granular material distributed over the yeast cell wall surface. However, the intensity of the reaction changed according to the cell growth phase. The cytochemical labelling intensity was greater in control samples with 8 hours of growth compared to those with 16 and 24 hours suggesting a natural modification in the surface expression of carbohydrate during cell aging.

Although significant progress has been achieved in the knowledgement of the structure of fungal wall polysaccharides, little is known about their organization on the cell surface. It has been proposed that cellular polysaccharides and lipids distribution and localization in microorganisms may vary with cultural conditions, phase of cell cycle, oxigen tension and temperature. By manipulating cell wall construction a fungus 
may assume a variety of functions $(4,7,21,26,29,30,31,50)$.

Cellular carbohydrate composition, content and distribution in the cell surface are very important in the cellular differentiation/maturation stages of an organism. Besides their structural role, the surface carbohydrates are associated to cell interaction and can act as receptors for extracellular substances and molecules, $(1,13,14,22,23,54)$. Alterations in the carbohydrate composition and distribution were observed in yeasts according to the growth phase and phase transition (dimorphism) by using biochemical degradative techniques (10, $24,58,59)$.

The acid polysaccharide presence was first demonstrated for Coccidioides immitis (45). Indeed, the presence of acidic carbohydrates in zygomycetes by using biochemical and enzimatic methods was also demonstrated (9).

Using ruthenium red, Edwards et al. (18) detected a dense cell coat in Paracoccidioides brasiliensis assexual spores. A thin coat was observed in the mycelium surface.

That the effects of surfactants on growth and lipase production by $C$. lipolytica were first observed using sodium dodecyl sulphate - a anionic surfactant $(41,42)$. Nascimento et al. (43) showed the effects of Tween 80 on protease production by $C$. lipolytica. The addition of Tween 80 to a $C$. lipolytica culture medium induced an increase in cellular viability, with maximum stimulation of enzyme production when added at the begining of culture. The highest stimulatory enzyme secretion was observed with Tween $801.0 \%$.

This work revealed that $C$. lipolytica cells grown in medium with Tween 80 exhibited differences on the presence and distribution of acid polysaccharides according to addition time and concentration of the surfactant. Cells treated with Tween $801.0 \%$ at the beginning of culture presented a no reaction product in spite of surfactant time addition. Treatment with Tween $800.5 \%$ treatment at 8 hours of culture induced a reduced acid polysaccharides labeling compared to control cells.

The effects of surfactants were demonstrated on cellular lipids of bacteria, in which the oleic acid could be introduced in the lipid bilayer of the cell membrane. Cells grown in the presence of Tween 80 exhibited an increase in the cellular lipid content $(55,61)$. However, the effect of Tween 80 on cellular polysaccharides was not studied. This work demonstrated for the first time the effect of surfactant on the surface polysaccharide of C. lipolytica.

Studies on effects of surfactants on cell ultrastructure are rare. However, some ultrastructural alterations were observed in bacteria of MAC complex grown in presence of Tween 80 by using transmission and scanning electron microscopy. Cell elongation, inhibition of formation of cell coat, appearance of cytoplasmic inclusion-like bodies and reduction of cell eletrondensity are some of the cellular changes $(17,35,36)$.

The results demonstrate for the first time the ultrastructural localization and distribution of acid polysaccharides in Candida lipolytica in different growth phases, and the effects of the addition of Tween 80 to the growth medium on the expression of these sugar residues. Also, this work demonstrated the effects of different carbon sources in the culture medium on the cellular carbohydrate content on the organism cell surface. The elucidation of the chemical nature of the cell wall is essential to infer the physiological and biochemical activities of the fungal cell.

By means of electron microscopy, it is possible to gain new insight into the organization and constitution of fungi cell wall at a level not revealed by routine methods. Much needs to be learned about fungi ultrastructure due to their importance, specially in medical and industrial fields.

\section{ACKNOWLEDGEMENT}

This work was supported by CNPq, FINEP, PRONEX and CAPES.

\section{RESUMO}

\section{Estudo citoquímico dos carboidratos ácidos na superfície de Candida lipolytica crescida em meio contendo Tween 80}

Moléculas contendo resíduos de açúcares foram localizadas sobre a superfície de Candida lipolytica utilizando-se o vermelho de rutênio como marcador citoquímico. A levedura foi semeada em meio contendo Tween 80 . O surfactante, nas concentrações de $1,0 \%$ e $0,5 \%$, foi adicionado ao meio de cultivo em diferentes intervalos de tempo, correspondentes ao início da fase exponencial de crescimento, meio da fase logarítmica e final da fase exponencial de crescimento, Culturas-controles foram cultivadas em meio contendo glicose como fonte de carbono. O crescimento da levedura em meios contendo glicose ou Tween 80 induziu o surgimento de alterações na distribuição e na localização de polissacarídeos ácidos na parede celular do organismo. Células crescidas em glicose ou Tween 80 exibiram variações citoquímicas em função de sua fase de crescimento. Adicionalmente, o padrão de marcação citoquímica também sofreu variações de acordo com a concentração do surfactante. A influência do surfactante na expressão de carboidratos é discutida.

Palavras-chave: Candida lipolytica; citoquímica de carboidratos; ultraestrutura de fungos.

\section{REFERENCES}

1. Ackerman, G. A, Freeman, W. H. Membrane differentiation of developing hemic cells of the bone marrow demonstrated by changes in concanavalin A surface labeling. J. Histochem. Cytochem., 27:1413-1423, 1979.

2. Akashi, T., Homma, M., Kanbe, T., Tanaka, K. Ultrastructure of ProteinaseSecreting Cells of Candida albicans Studied by Alkaline Bismuth Staining and Immunocytochemistry. J. Gen. Microbiol., 139:2185-2195, 1993. 
3. Asther, M., Corrieu, G. Effect of Tween 80 and oleic acid on ligninase production by Phanerochaete chrysosporium INA-12. Enz. Microbiol. Technol., 9:245-249, 1987.

4. Bartinicki-Garcia, S. Cell Wall Chemistry, Morphogenesis, and Taxonomy of Fungi. Ann. Rev. Microbiol., 22:87-108, 1968.

5. Bendayan, M.; Benhamou, N. Ultrastructural Localization of Glucoside Residues on the Tissue Sections by Applying the Enzyme-Gold Approach. J. Histochem. Cytochem., 35:1149-1155, 1987.

6. Berbee, M. L. Ultrastructural and Light Microscopic Localization of Carbohydrates and Peroxidase/Catalase in Lagenidium giganteum Zoospores. Mycologia, 85: 734-743, 1993.

7. Cabib, E., Dragon, T., Drgonova, J., Ford, R. A ., Kollar, R. The yeast cell wall, a dynamic structure engaged in growth and morphogenesis. Biochem. Soc. Trans., 25:200-204, 1997.

8. Campo-Aasen, I.; Goihman-Yahr, M. Adenosine Triphosphatase in Yeast Phase of Paracoccidioides brasiliensis. Mycopathologia, 111:169-172, 1990.

9. Campos Takaki, G. M. Aspectos Bioquímicos e Ultraestruturais das Paredes Celulares de Fungos da Ordem Mucorales (Zygomycetes). Tese de Doutoramento. Universidade de São Paulo. 1984, 242 p.

10. Cassone, A, Simonetti, N., Strippoli, V. Ultrastructural Changes in the Wall During Germ-Tube Formation from Blastospores of Candida albicans. J. Gen. Microbiol., 77:417-426, 1973.

11. Cirigliano, M. C., Carman, G. M. A Plating Technique for the Selective Isolation of Yeast Utilizing Water Miscible Carbon. J. Food Sci., 48:15541555,1983

12. Cirigliano, M. C., Carman, G. M. Isolation of a Bioemulsifier from Candida lipolytica. Appl. Environm. Microbiol., 48:747-750, 1984.

13. De Souza, W. Components of the Cell Surface of Trypanosomatids. Progr. Protistol., 3: 87-184, 1989.

14. Debono, M., Gordee, R. S. Antibiotics That Inhibit Fungal Cell Wall Development. Ann. Review Microbiol., 48:471-497, 1994.

15. Dielbandhoesing, S. K., Zhang, H., Caro, L. H. P., van der Vaart, J. M., Klis, F. M., Verrips, C. T., Brul, s. Specific Cell Wall Protein Confer Resistance to Nisin upon Yeast Cells. Appl. Environm. Microbiol., 64:40474052, 1998

16. Djaczenko, W., Cassone, A Visualization of New Ultrastructural Components in the Cell Wall of Candida albicans with Fixatives Containing TAPO. J. Cell Biol., 52:186-190, 1971.

17. Dubos, R. J., Davis, B. D. Factors Affecting the Growth of Tubercle Bacilli in Liquid Media. J. Exp. Med., 83:409-423, 1946.

18. Edwards, M. R., Salazar, M. E., Samsonoff, W. A, Cano, L. E., Ostrander, G., Restrepo, A . Electron Microscopic Study of Conidia Produced by the Mycelium of Paracoccidioides brasiliensiensis. Mycopathologia, 114:169-177, 1991

19. Espinosa, E., Sanchez, S., Farres, A. Nutritional Factors Affecting Lipase Production by Rhizopus delemar CDBB H313. Biotechnol. Lett., 12:209214, 1990.

20. Evron, R., Drewe, A. Demonstration of the Polysaccharides in the Cell Wall of Candida albicans Blastospores, Using Silver Methenamine Staining and a Sequence of Extraction Procedures. Mycopathologia, 84:141-149, 1983.

21. Farkas, V. Biosynthesis of Cell Wall of Fungi. Microbiol. Ver., 43:117144, 1979.

22. Gander, J. E. Fungal Cell Wall Glicoproteins and Peptido-Polysaccharides. Ann. Rev. Microbiol., 28:103-119, 1974.

23. Hanai, T., Usuda, N., Morita, T., Nagata, T. Light Microscopic Lectin Histochemistry in Aging Mouse Kidney: Study of Composicional Changes in Glycoconjugates. J. Histochem. Cytochem., 42:897-906, 1994.

24. Herrero, E., Sanz, P., Sentandreu, R. Cell Wall Proteins Liberated by Zymolase from Several ascomycetes and Imperfect Yeasts. J. Gen. Microbiol., 133:2895-2903, 1987.

25. Hockstenback, F., Klis, F. M., van den Ende, H., van Donselaar, E., Peters, P. J., Klausner, R. D. Identification of a Putative alpha-glucan Synthase Essential for Cell Wall Construction and Morphogenesis in Fission Yeast. Proc. Natl. Acad. Sci. USA, 95:9161-9166, 1998.

26. Jimenez-Barbero, J., Prieto, A, Gomez-Miranda, B., Leal, J. A, Bernabe, M. Chemical Structure of Fungal Cell-Wall Polysaccharides Isolated from Microsporum gypseum and Related Species of Microsporum and Trychophyton. Carbohydr. Res., 272:121-128, 1995.
27. Jouault, T., R., Fradin, C., Trinel, P. A, Bernigaud, A, Poulain, D. Early Signal Transduction Induced by Candida albicans in Macrophages through Shedding of a Glycolipid. J. Infect. Dis., 178:792-802, 1998.

28. Klomparens, K. L. The Development and Application of Ultrastructural Research in Mycology. Mycopathologia, 109:139-148, 1990.

29. Kollar, R., Petrakova, E., Ashwell, G., Robbins, P. W., Cabib, E. Architecture of the Yeast Cell Wall. The Linkage beTween Chitin and b(1 $\rightarrow 3)$-Glucan. J. Biol. Chem., 270:1170-1178, 1995.

30. Leal, J. A, Jimenez- Barbero, J., Gomez-Miranda, B., Parra, E., Prieto, A, Domenech, J., Bernabe, M. Structural Investigation of Cell-Wall Galactomannan from Neurospora crassa and N. sitophila. Carbohydr. Res., 283:215-222, 1995.

31. Lipke, P. N., Ovalle, R. Cell Wall Architecture in Yeast: New Structure and New Challenges. J. Bacteriol., 180:3735-3740, 1998.

32. Luft, J. H. Electron Microscopy of Cell Extraneous Coats as Revealed by Ruthenium Red Staining. J. Cell Biol., 23:54-55 A, 1964.

33. Luft, J. H. Ruthenium Red and Violet. II. Fine Structural Localization in Animal Tissues. Anat. Res. 171:369-416, 1971.

34. Luft, J. H. The Structure and Properties of the Cell Coat. Int. Rev. Cytol., 45:291-382, 1976.

35. Masaki, S., Sugimori, G., Okamoto, A , Imose, J., Hayashi, Y. Effect of Tween 80 on the Growth of Mycobacterium avium Complex. Microbiol. Immunol., 34:653-663, 1990.

36. Masaki, S., Sugimori, G., Okamoto, A , Inoue, J., Hayashi, Y. Effect of Tween 80 on Formation of the Superficial L1 Layer of the Mycobacterium avium - Mycobacterium intracellulare Complex. J. Clin. Microbiol., 29:1453-1456, 1991.

37. Matsuoka, M., Ueda, Y., Aiba, S. Cytoplasmic Transfer of Olygomicin Resistance During Protoplast Fusion of Saccharomycopsis lipolytica. J. Bacteriol., 152:530-533, 1980.

38. Mattey, M., Morgan, D. Secretion of Extracellular Proteolysis by Candida lipolytica. Mycologia, 69:646-651, 1977.

39. Moruno, E. G., Delfini, C., Pessione, E., Giunta, C. Factors Affecting Acetic Acid Production by Yeasts in Strongly Clarified Grape Musts. Microbios, 74:249-256, 1993.

40. Mims, C. W. Using Electron Microscopy to Study Plant Pathogenic Fungi. Mycologia, 69:309-320, 1991.

41. Nascimento, A E., Campos Takaki, G. M. Effects of Sodium Dodecyl Sulfate on Lipase of Candida lipolytica. Appl. Biochem. Biotechnol., 49:93-99, 1994.

42. Nascimento, A E., Campos Takaki, G. M. Effects of Sodium Dodecyl sulfate on the Growth of Candida lipolytica. Rev. Bras. Microbiol., 26:140$143,1995$.

43. Nascimento, A E., Nascimento Allana, E., Campos Takaki, G. M. Effects of Tween 80 on Protease Production by Candida lipolytica. Bol. Micol., 12:75-78, 1997.

44. Ogrydziak, D. M., Mortimer, R. K. Genetics of Extracellular Protease Production in Saccharomycopsis lipolytica. Genetics, 87:621-632, 1977.

45. O'hearn, E. M., Henry, B. S. A Cytological Study of Coccidioides immitis by Electron Microscopy. J. Bacteriol., 72: 632-645, 1956.

46. Okeke, C. N., Okolo, B. N. The Effects of Cultural Conditions on the Production of Lipase by Acremonium strictum. Biotechnol. Lett., 12:747750, 1991.

47. Osumi, M. Development of Methods for Observing of Bacteria and Fungi by Electron Microscopy. J. Electron Microsc., 38:SI50-SI55, 1989.

48. Osumi, M. The Ultrastructure of Yeast: Cell Wall Structure and Formation. Micron, 29:203-233, 1998.

49. Pareilleux, A. Hydrocarbons Assimilation by Candida lipolytica: Formation of a Biossurfactant. Effects on Respiratory Activity and Growth J. Appl. Microbiol. Biotechnol., 8:91-101, 1979.

50. Prieto, A, Leal, J. A, Poveda, A, Jimenez-Barbero, J., Gomez-Miranda, B., Domenech, J., Ahrazem, O, Bernabe, M. Structure of Complex Cell Wall Polysaccharides Isolated from Trichoderma and Hypocrea Species. Carbohydr. Res., 304:281-291, 1997.

51. Ramanandraibe, E., Younsi, M., Coulon, J., Loppinet, V., Hakkou, A, Bonaly, R. Implication of Cell Wall Constituents in the Sensitivity of Kluyveromyces lactis Strains to Amphotericin B. Res. Microbiol., 149:109-118, 1998. 
52. Rose, D. L., Tully, J. G., Bove, J. M., Whitcomb, R. F. A Test for Measuring Growth Responses of Mollicutes to Serum and Polyoxyethylene Sorbitan. Int. J. Syst. Bacteriol., 43:5227-532, 1993.

53. Ruiz-HerrerA, J., Leon, C. G., Carabez-Trejo, A, Reyes-Salinas, E. Structure and Chemical Composition of the Cell Walls from the Haploid Yeast and Mycelial Forms of Ustilago maydis. Fungal Gen. Biol., 20:133142, 1996.

54. San-Blas, G. The Cell Wall of Fungal Human Pathogen: Its Possible Role in Host-Parasite Relationship. A Review. Mycopathology, 79:159-184, 1982.

55. Stinson, M. W., Solorotovsky, M. Interaction of Tween 80 Detergent with Mycobateria in Synthetic Medium. Amer. Rev. Resp. Dis., 104:717-727, 1971.

56. Takamiya, H., Vogt, A., Batsford, S., Kuttin, E. S., Muller, J. Further Studies on the Immunoelectronmicroscopic Localization of Polysaccharide Antigens on Ultra-Thin Sections of Candida albicans. Mykosen, 28:1732, 1984.
57. Takeo, K.; Mine, H.; Sano, A ; Nishimura, K.; Miyaji, M. Comparison of Yeast Plasma Membrana Ultrastucture of Various Fungal Taxa. Proceedings of the Fourth International Symposium of the Research Center for Pathogenic Fungi and Microbial Toxicoses, Chiba University. 1989, p.81-84.

58. Takeo, K., Mine, H., Nishimura, K., Miyaji, M., The Existence of a Dispensable Fibrillar Layer on the Wall Surface of Mycelial but not Yeast Cells of Aureobasidium pullulans. FEMS. Microbiol. Lett., 111:153-158, 1993.

59. Vega, R., Dominguez, A. Cell Wall Composition of the Yeast and Mycelial Forms of Yarrowia lipolytica. Arch. Microbiol., 144:124-130, 1997.

60. Wickerham, L. J., Kurtzman, C. P., Herman, A I. Sexual Reproduction in Candida lipolytica. Science, 167:1141, 1970.

61. Wittenberger, C. L., Beaman, A J., Lee, L. N. Tween 80 Effect on Glucosyltransferase Synthesis by Streptococcus salivarius. J. Bacteriol., 133:231-239, 1987.

62. Yamada, T., Ogrydziak, D. M. Extracellular Acid Protease Produced by Saccharomycopsis lipolytica. J. Bacteriol., 154, 23-31, 1991. 